\title{
PENGARUH PENERAPAN METODE MIND MAPPING TERHADAP KEMAMPUAN BERPIKIR KREATIF SISWA
}

\author{
Arrofa Acesta \\ Program Studi Pendidikan Guru Sekolah Dasar, Universitas Kuningan \\ Jl. Cut Nyak Dhien No.36 A, Cijoho, Kec. Kuningan, Kabupaten Kuningan, Jawa Barat 45513 \\ Email: arrofa.acesta@uniku.ac.id
}

\begin{abstract}
This research is motivated by the low ability of students' creative thinking which is only about $40 \%$ of students who can meet the Minimum Mastery Criteria (KKM). Objectives The purpose of this study is to learn how to improve students' thinking abilities by using the Mind Mapping method. This research was conducted in fifth grade students of SDN 2 Mekarwangi Kuningan District. This study uses a pre-experimental research method. The results showed that the use of mind mapping can improve students' creative thinking abilities about research, the results obtained increased when the pretest was obtained an average of 45.42 and the posttest obtained an average of 83.79 it was a mapping method thoughts designed to support students 'thinking that can develop ideas and planning to solve problems using mind mapping, so that it can be concluded that is related to the mind mapping method of students' creative thinking abilities.
\end{abstract}

Keywords:

Mind Mapping Method; Creative Thinking.

\begin{abstract}
Abstrak
Penelitian ini dilatarbelakangi oleh rendahnya kemampuan berpikir kreatif siswa yang hanya sekitar $40 \%$ siswa yang dapat mencapai Kriteria Ketuntasan Minimal (KKM). Tujuan Tujuan penelitian ini adalah untuk mengetahui peningkatan kemampuan berpikir kreatif siswa dengan menggunakan Pendekatan metode Mind Mapping. Penelitian ini dilaksanakan pada siswa kelas V SDN 2 Mekarwangi Kabupaten Kuningan. Penelitian ini menggunakan metode penelitian pre eksperimen Hasil penelitian menunjukan bahwa penggunaan pendekatan mind mapping dapat meningkatkan kemampuan berpikir kreatif siswa berdasarkan hasil penelitian didapat hasil yang meningkat yaitu pada pada pretest diperoleh rata-rata 45,42 dan pada posttest diperoleh ratarata 83,79 selain itu metode mind mapping berpengaruh pada kemampuan berpikir kreatif siswa terlihat bahwa siswa lebih dapat mengembangkan ide-ide dan gagasan untuk menyelesaikan masalah dengan menggunakan mind mapping, sehingga dapat disimpulkan bahwa terdapat pengaruh metode mind mapping terhadap kemampuan berpikir kreatif siswa.
\end{abstract}

Kata Kunci:

Metode Mind Mapping; Berpikir Kreatif.

\section{A. PENDAHULUAN}

Pembelajaran merupakan proses interaksi antara guru dengan siswa dan sumber belajar pada suatu lingkungan belajar yang meliputi guru dan siswa bertukar informasi. Menurut Usman (2012: 12) pembelajaran adalah inti dari proses pendidikan secara keseluruhan dengan guru sebagai pemegang peranan utama. Pembelajaran merupakan suatu proses yang mengandung serangkaian perbuatan guru dan siswa atas dasar hubungan timbal balik yang berlangsung dalam situasi edukatif untuk mencapai tujuan tertentu.

Pada umumnya pelaksanaan proses pembelajaran masih menggunakan metode yang konvensional dan lebih dominan guru sebagai subjek pembelajaran, dimana siswa hanya mendengarkan saja dan diberikan tugas membaca dan hanya mengisi soal saja, dimana guru tidak memberi tugas yang dapat merangsang kreativitas siswa dan tidak memotivasi siswa agar semangat dalam pembelajaran dan mengerjakan tugas. Akibatnya siswa kurang termotivasi dalam pembelajaran dan kurang mengembangkan 581 | Naturalistic: Jurnal Kajian Penelitan dan Pendidikan kemampuan berpikir kreatifnya. Hal ini diperkuat dengan hasil wawancara dengan guru kelas $\mathrm{V}$ sebagai berikut : "Kemampuan berpikir kreatif di SD masih terlihat kurang dalam proses pembelajaran terutama pada mata pelajaran Ilmu Pengetahuan Alam. Hal ini ditunjukan dengan beberapa siswa yang nilainya belum memenuhi standar ketuntasan belajar atau kurang dari Kriteria Ketuntasan Minimal (KKM) yang ditentukan oleh pihak sekolah, terlihat bahwa masih ada beberapa siswa kelas $\mathrm{V}$ yang belum mencapai KKM, salah satunya dalam berfikir kreatif. Padahal KKM telah ditetapkan adalah 70 dengan jumlah siswa 21 orang, bukan hanya itu saja pembelajaran di kelas sangat membosankan itu mempengaruhi motivasi siswa untuk berpikir kreatif".

Berdasarkan hasil wawancara dan observasi dengan guru kelas $\mathrm{V}$ yang penulis laksanakan di SD Negeri 2 Mekarwangi tersebut dapat diketahui bahwa kemampuan berpikir kreatif siswa masih terlihat kurang atau rendah, hal ini dibuktikan masih banyaknya siswa yang nilainya masih 
dibawah KKM. Dimana berpikir kreatif merupakan berpikir tingkat tinggi yang mempunyai beberapa indikator yaitu kelancaran, kelenturan, keaslian dan elaborasi yang dapat berpengaruh kepada kognitif siswa, jadi kemampuan berpikir kreatif dapat mempengaruhi KKM, karena jika nilai KKM rendah maka kemampuan berpikir kreatif siswa rendah, sedangkan sistem pembelajaran yang bersifat menghafal dirasa kurang efektif untuk siswa, menghafal pada dasarnya hanya untuk jangka waktu pendek. Ketika satu minggu berlalu maka peserta didik perlu mengingat kembali, maka dengan pembelajaran yang bersifat mengembangkan kemampuan berpikir kreatif siswa akan mampu menghasilkan gagasan baru atau menghasilkan sebuah pemikiran baru, lancar dalam mengungkapkan gagasan-gagasannya dan menghasilkan banyak ide untuk memecahkan masalah.

Karakter tidak dapat dibentuk dalam waktu sekejap, melainkan harus ditanamkan sejak usia dini dan dipupuk hingga usia dewasa, oleh karena itu kurikulum 2013 memfokuskan pada pendidikan karakter. Mind mapping adalah teknik untuk memaksimalkan daya kerja otak dengan cara membuat alur-alur berpikir. Mind mapping mampu meningkatkan hasil belajar serta meningkatkan kreativitas peserta didik, hal ini dikarenakan di dalam pembuatan mind map juga terdapat penggunaan simbol, gambar, garis dan warna yang dapat merangsang pola pikir kreatif dimana siswa menganggap bahwa mind map itu teknik mencatat yang menyenangkan.

Kemampuan berpikir kreatif siswa tidak terlepas dari dorongan atau motivasi guru, kemampuan berpikir kreatif siswa akan tumbuh atau terus berkembang jika guru dalam pembelajaran mampu merangsang siswa untuk berpikir kreatif, sehingga siswa termotivasi dalam pembelajaran atau dalam mengerjakan tugas sekalipun dan siswa dapat dengan mudah juga untuk memahami pembelajaran. Untuk itu guru harus lebih berinovasi dalam pembelajaran agar siswa termotivasi, salah satunya yaitu dengan pemilihan metode pembelajaran. Metode adalah sebuah cara guru dalam menyampaikan materi pembelajaran secara teratur dalam rangka mencapai tujuan belajar. Guru dituntut untuk lebih kreatif dalam menggunakan metode pembelajaran agar dapat menarik minat siswa dalam belajar. Selain faktor guru, faktor kemampuan dan kemauan siswa berpikir kreatif juga sangat berpengaruh terhadap kesuksesan pembelajaran. Hasil penelitian yang telah dilakukan oleh Hardiyanto pada tahun 2013 menunjukkan bahwa penerapan Mind Mapping terbukti efektif dalam meningkatkan kemampuan belajar IPA pada siswa kelas IV.

\section{B. HASIL DAN PEMBAHASAN}

Berdasarkan hasil penelitian yang telah dilakukan menunjukkan bahwa $\mathrm{Hi}$ diterima dan H0 ditolak, artinya bahwa dari satu kelas yang dilakukan dengan menggunakan tes awal (pretest) dan tes akhir (posttest) maka terdapat pengaruh metode mind mapping terhadap kemampuan berpikir kreatif siswa kelas V SD Negeri 2 Mekarwangi Kecamatan Lebakwangi Kabupaten Kuningan tahun pelajaran 2018-2019. Hal ini dapat dilihat dari hasil tes awal (pretest) dengan jumlah siswa 21 orang diperoleh rata-rata 45,42 dengan nilai tertinggi 67 dan nilai terendah 27 dan standar deviasinya 11,11 dan hasil tes akhir (posttest) dengan jumlah siswa 21 orang diperoleh rata-rata 83,79 dengan nilai tertinggi 92 dan nilai terendah 67 dan standar deviasinya 11,45 . Hal ini menunjukkan bahwa hasil pretest sebelum menggunakan metode mind mapping dan hasil posttest setelah menggunakan metode mind mapping memiliki rata-rata yang berbeda.

Pembelajaran dengan menerapkan metode mind mapping sangat berpengaruh terhadap kemampuan berpikir kreatif karena dalam proses pembelajaran siswa sangat berantusias untuk mengikutinya, hasil yang didapatkan setelah pembelajaran ini sangat memuaskan serta terbentuknya pola pikir kreatif siswa dimana siswa mampu memikirkan dan menemukan sesuatu yang baru, menciptakan gagasan-gagasan baru, dan mampu memandang suatu masalah dari berbagai sudut pandang. Hal tersebut ditandai dengan diantaranya siswa yang tadinya tidak mampu menghubungkan antara syarat air yang baik untuk kehidupan sehari-hari itu berbedabeda, dengan pengembangan kemampuan berpikir kreatif siswa jadi mampu mengetahui hubungan syarat-syarat air yang baik untuk kehidupan sehari-hari seperti apa. Hal ini didukung dengan hasil penelitian yang dilakukan oleh Nugroho tahun 2011 yang mengatakan bahwa penggunaan mind map dalam pembelajaran telah mempermudah siswa dalam memahami materi pelajaran karena mereka jadi mengetahui arah pembelajaran yang dilakukan kemana dan mengetahui kaitan atau hubungan antara materi satu dengan materi yang lain. Hasil penelitian 
Nugroho menunjukkan bahwa metode mind map dapat meningkatkan kreativitas siswa ditunjukkan dengan hasil penelitian yang terus mengalami peningkatan setiap siklusnya (Nugroho, 2011).

Belum banyak guru yang menerapkan metode yang dapat mengasah kemampuan berpikir kreatif siswa, padahal tantangan masa depan menuntut pembelajaran harus lebih mengembangkan kemampuan berpikir kreatif siswa. Metode pembelajaran yang dapat mengasah kemampuan berpikir kreatif siswa salah satunya yaitu metode mind mapping, karena metode ini menggunakan pengingat-pengingat visual dengan membentuk pola dan ide-ide yang berkaitan yang digunakan untuk belajar. Mind mapping ini dapat mengembangkan ide-ide orisinal dan memicu ingatan dengan mudah. Pada saat pembelajaran dengan konsep air untuk kebutuhan sehari-hari siswa diberikan selembar kertas kosong untuk membuat mind map, sebelumnya siswa diperlihatkan contoh mind map kemudian siswa diberi penjelasan mengenai bagaimana cara membuat mind map, selanjutnya siswa membuat mind map mengenai air untuk kebutuhan seharihari disini siswa dituntut menggunakan indikator kemampuan berpikir kreatif. Beberapa indikator kemampuan berpikir kreatif diantaranya yaitu kemahiran/kelancaran, kelenturan, keaslian dan elaborasi (Utari Sumarno, dkk. 2012: 20).

Mind map adalah suatu teknik mencatat yang mengembangkan gaya belajar visual karena cara membuatnya yaitu dengan meletakan topik utama atau inti dari pembahasan sebuah materi di tengah dan membuat cabang-cabang, symbol, gambar maupun warna sehingga lebih menarik, adanya kombinasi warna, simbol, bentuk dan sebagainya memudahkan otak dalam menyerap informasi yang diterima. Berpikir kreatif yang dimaksud dalam model mind mapping merupakan cara berpikir siswa secara lancar dan luwes, dimana siswa akan menjadi lancar berpikir dan mengemukakan gagasan-gagasannya serta menemukan alternatif jawaban dengan beragam (Zainal Aqib, 2013: 23). Pola berpikir kreatif disebut pola berpikir divergen atau berpikir secara menyeluruh. Bagi siswa yang kreatif maka akan menganalisis suatu permasalahan dan menemukan berbagai alternatif jawaban dilihat dari berbagai sudut pandang.

Kemampuan berpikir kreatif pada saat siswa membuat mind map terlihat dimana siswa menyatakan syarat air yang baik untuk minum dan masak yaitu air tidak keruh, tidak berwarna apapun, tidak berbau apapun, tidak berasa apapun, tidak asin dan tidak meninggalkan endapan, disini siswa menunjukkan indikator kelancaran dimana siswa lancar mengungkapkan gagasangagasannya. Siswa juga menyatakan gagasan yang bersifat luwes/kelenturan, dimana siswa menyatakan jawaban yang bervariasi, seperti saat menjawab syarat air untuk mencuci pakaian siswa menjawab air yang segar, tidak asin dan tidak kotor. Adapun siswa menyatakan ungkapan baru dan unik seperti saat menjawab syarat air untuk menyiram tanaman siswa menjawab tidak mengandung penyakit seperti disentri, tifus dan kolera, disini siswa menunjukkan indikator keaslian. Selanjutnya di dalam materi siklus air dan bencana kekeringan saat ada pertanyaan perbedaan air tanah dengan air permukaan ada siswa yang menjawab air tanah tersaring oleh lapisan tanah dan akar tumbuhan, dan air permukaan biasanya lebih kotor karena menyatu dengan lumpur dan macam material dari proses erosi, disini menunjukkan indikator elaborasi karena siswa mampu mengembangkan suatu gagasan atau produk, merinci detail-detail dari suatu objek, gagasan, atau situasi sehingga menjadi lebih menarik.

Berdasarkan penelitian yang peneliti lakukan, dapat disimpulkan bahwa penerapan metode mind mapping dapat memberikan dampak positif dalam pembelajaran. Hal ini terbukti dengan adanya pengaruh meningkatnya kemampuan berpikir kreatif siswa sebelum menerapkan metode mind mapping dengan setelah menerapkan metode mind mapping. Dari penelitian ini saya melakukan tes awal (pretest) dilakukan sebelum kelas tersebut diberi perlakuan dengan tujuan untuk mengetahui kemampuan awal siswa sebelum dilakukan proses pembelajaran. Selanjutnya kelas diberikan pembelajaran dengan menggunakan metode mind mapping, kemudian kelas diberikan tes akhir (posttest) untuk mengetahui pengaruh kemampuan berpikir kreatif siswa menggunakan metode mind mapping.

Adapun hasil tes awal (pretest) dengan jumlah siswa 21 orang diperoleh rata-rata 45,42 dengan nilai tertinggi 67 dan nilai terendah 27 dan standar deviasinya 11,11 dan hasil tes akhir (posttest) dengan jumlah siswa 21 orang diperoleh rata-rata 83,79 dengan nilai tertinggi 92 dan nilai terendah 67 dan standar deviasinya 11,45. Hal ini menunjukkan bahwa hasil pretest setelah sebelum menerapkan metode mind mapping dan hasil posttest setelah menerapkan metode mind 
mapping memiliki rata-rata yang berbeda. Dari data tersebut maka langkah selanjutnya yaitu melakukan pengujian uji normalitas, hasil uji normalitas diperoleh dengan mengambil taraf signifikansi 0,05 sedangkan hasil uji hipotesis diperoleh dengan mengambil taraf signifikansi 0,05 . Hasil uji normalitas data pretest di diperoleh $\mathrm{X} 2$ Hitung $=1,77$ dengan mengambil taraf signifikansi 0,05 dengan $\mathrm{X} 2$ Tabel $=5,99$, sedangkan hasil uji normalitas data posttest diperoleh X2 Hitung = 6,26 dengan mengambil taraf signifikansi 0,05 dengan X2 Tabel $=7,81$. Maka dapat disimpulkan bahwa data pretest dan data posttest setelah diuji normalitas didapat hasil X2hitung $<$ X2tabel yang diartikan bahwa data tersebut berdistribusi normal. Dengan demikian, dari data tersebut dapat dijadikan acuan untuk melakukan uji hipotesis.

Analisis hipotesis dengan hasil perhitungan diperoleh nilai t hitung sebesar 16,36 dan nilai signifikan $(\alpha)$ sebesar 0,05 diperoleh $\mathrm{t}$ tabel sebesar 2,09 dengan demikian dapat disimpulkan bahwa t hitung $>$ dari t tabel atau 16,36 > 2,09. Hal ini menyatakan bahwa terdapat penerimaan hipotesis penelitian $(\mathrm{H} 1)$ dan penolakan hipotesis penelitian (H0). Maka dapat dinyatakan bahawa $\mathrm{H} 1$ diterima dan $\mathrm{HO}$ ditolak, yang artinya adanya pengaruh yang positif pada kemampuan berpikir kreatif siswa dengan menerapkan metode mind mapping kelas $\mathrm{V}$ pada muatan Ilmu Pengetahuan Alam. Dengan kata lain, metode mind mapping berpengaruh terhadap kemampuan berpikir kreatif siswa kelas V pada muatan Ilmu Pengetahuan Alam.

\section{SIMPULAN}

Berdasarkan hasil penelitian didapat hasil yang meningkat yaitu pada pada pretest diperoleh ratarata 45,42 dengan nilai tertinggi 67 dan terendah 27 dengan SD 11,11 dan pada posttest diperoleh rata-rata 83,79 dengan nilai tertinggi 92 dan terendah 67 dengan SD 11,45, selain itu metode mind mapping berpengaruh pada kemampuan berpikir kreatif siswa terlihat bahwa siswa lebih dapat mengembangkan ide-ide dan gagasan untuk menyelesaikan masalah dengan menggunakan mind map, sehingga dapat disimpulkan bahwa terdapat pengaruh metode mind mapping terhadap kemampuan berpikir kreatif siswa, dengan demikian $\mathrm{Hi}$ diterima dan $\mathrm{HO}$ ditolak. Hal ini didukung oleh uji normalitas yaitu $\mathrm{X}_{\text {hitung }}^{2}<\mathrm{X}_{\text {tabel }}^{2}$ dan hasil uji $t$ yang menyatakan $t$ hitung $>t$ tabel atau $16,36>2,09$. Hal ini menyatakan bahwa terdapat penerimaan hipotesis penelitian $\left(\mathrm{H}_{1}\right)$ dan penolakan hipotesis penelitian $\left(\mathrm{H}_{0}\right)$.

Maka dapat ditarik kesimpulan bahwa metode mind mapping berpengaruh positif terhadap kemampuan berpikir kreatif siswa pada muatan IPA kelas $\mathrm{V}$ di SD Negeri 2 Mekarwangi Kecamatan Lebakwangi Kabupaten Kuningan. Hal ini menunjukkan bahwa penerapan Metode Mind Mapping berpengaruh dalam meningkatkan kemampuan berpikir kreatif siswa.

\section{DAFTAR PUSTAKA}

Abidin, Yunus. (2012). Pembelajaran Bahasa Berbasis Pendidikan Karakter. Bandung: PT Refika Aditama.

Aqib, Zainal. (2013). Model-model, Media, dan Strategi Pembelajaran Kontekstual (Inovatif). Bandung: CV Yrama Widya.

Arifin, Zainal. (2017). Evaluasi Pembelajaran. Bandung: Remaja Rosdakarya.

Arikonto, Suharsimi. (2016). Prosedur Penelitian Suatu Pendekatan Praktik. Jakarta: PT Rineka Cipta

Azizah, Susis Nur. (2015). Penerapan Metode Mind Mapping Siswa Kelas V SD Negeri Jomblangan Banguntapan Bantul. Skripsi pada PGSD FIP UNY. Yogyakarta: tidak diterbitkan.

Buzan, Tony. (2013). Buku Pintar Mind Map. Jakarta: Gramedia Pustaka Utama

Darusman, Rijal. (2014). Penerapan Metode Mind Mapping (Peta Pikiran) Untuk Meningkatkan Kemampuan Berpikir Kreatif Matematik Siswa SMP. Jurnal Ilmiah Program Studi Matematika STKIP Siliwangi Bandung, Vol. 3, No.2. Diakses 22 Januari 2019

Gebya dan Dian. (2012). The Assessment of Student's Mind Mapping Result on Limited Trial Towards Bilingual Interactive E-Book Media Through Mind Mapping Strategy on Chemical Bonding Matter for SMA RSBI. Unesa Journal of Chemical Education. 1/1: 115-123. Accessed 08/02/19

Hardiyanto, Y.D. (2013). Skripsi: "Penerapan Mind Mapping Sebagai Media Dalam Meningkatkan Kemampuan Belajar IPA Pada Siswa Kelas IV SD Negeri 1 Sengare Kabupaten Pekalongan" Universitas Negeri Semarang

Huda, Miftahul. (2017). Model-model Pengajaran dan Pembelajaran. Yogyakarta: Pustaka Belajar 
Kadir, Abdul. (2015). Menyusun dan Menganalisis Tes Hasil Belajar. Jurnal AlTa'dib Vol. 8 No. 2. Halaman 70-81. Diakses 20 Januari 2019

Nugroho, N.R.C. (2011). Skripsi: Penggunaan Metode Pembelajaran Mind Map untuk Meningkatkan Kreativitas dan Hasil Belajar Ekonomi Siswa Kelas X Di SMA MTA Surakarta Tahun Ajaran 2010/2011. Universitas Sebelas Maret

Pratini, D.A.M.M.O, dkk. (2013). Pengaruh Metode Mind Mapping Terhadap Keterampilan Berpikir Kreatif Dan Prestasi Belajar IPS. Jurnal Pendidikan Dasar Volume 3. Diakses 22 Januari 2019

Sanjaya, Wina. (2008). Perencanaan dan Desain Sistem Pembelajaran. Jakarta: Kencana Prenada Media Grup

Shoimin, Aris. (2017). Model Pembelajaran Inovatif dalam Kurikulum 2013. Yogyakarta: Ar-Ruzz Media

Sugiyono. (2011). Metode Penelitian Kuantitatif, Kualitatif dan $R \& D$. Bandung: Alfabeta

Sugiyono. (2017). Metode Penelitian Pendidikan. Bandung: Alfabeta

Sugiyono. (2016). Metode Penelitian Kuantitatif Kualitatif dan Kombinasi (Mixed Methods). Bandung: Alfabeta

Suhaerah, Lilis. (2014). Pengantar Statistik. Bandung Universitas Pasundan

Sumarmo, Utari, dkk. (2012). Kemampuan dan Disposisi Berpikir Logis, Kritis, dan Kreatif Matematik. Jurnal Pengajaran MIPA. Volume 17, Nomor 1. Diakses 31 Januari 2019

Swadarma, Doni. (2013). Penerapan Mind Mapping dalam Kurikulum Pembelajaran. Jakarta: PT Elex Media Komputindo

Syafi'I, Wan, dkk. (2011). Kemampuan Berpikir Kreatif dan Penguasaan Konsep Siswa Melalui Model Problem Based Learning (PBL) dalam Pembelajaran Biologi Kelas XI IPA SMAN 2 Pekanbaru Tahun Ajaran 2010/2011. Jurnal Biogenesis. Vol. 8, Nomor 1. Diakses 21 Januari 2019

Taniredja, T, dkk. (2015). Model-model Pembelajaran Inovatif dan Efektif. Bandung: Alfabeta

Usman, Husaini. (2013). Manajemen Teori, Praktik, dan Riset Pendidikan. Edisi Keempat. Jakarta Timur: Bumi Aksara

Utami, H.R. (2013). Keefektifan Penggunaan Model Mind Mapping Materi Sumber Daya
Alam Terhadap Hasil Belajar Siswa Kelas IV SD Negeri 03 Majalangun Watukompoi Kabupaten Pemalang. Semarang: Universitas Negeri Semarang

Wulandari, Wiwin, dkk. (2011). Problem Based Learning Untuk Meningkatkan Keterampilan Berpikir Kreatif Dan Penguasaan Konsep Siswa Pada Materi Larutan Penyangga. Jurnal Pengajaran MIPA. Volume 16, Nomor 2. Diakses 24 Januari 2019

Yamin, Martinis. (2013). Strategi \& Metode dalam Model Pembelajaran. Jakarta: Referensi (GP Press Group) 